\title{
Exploring diet in an isolated medieval rural community of Northern Iberia: The case study of San Baudelio de Berlanga (Soria, Spain)
}

\author{
Sylvia A. Jiménez-Brobeil ${ }^{a, *}$, Rosa M. Maroto ${ }^{a}$, Zita Laffranchi ${ }^{a}$, María G. Roca ${ }^{a}$, \\ Arsenio Granados Torres ${ }^{\mathrm{b}}$, Antonio Delgado Huertas ${ }^{\mathrm{b}}$ \\ ${ }^{a}$ Department of Legal Medicine, Toxicology and Physical Anthropology, Faculty of Medicine, University of Granada, Spain \\ ${ }^{\mathrm{b}}$ Biogeochemistry of Stable Isotopes Laboratory, Andalusian Institute of Earth Sciences, (IACT-CSIC-UGR), Spain
}

\section{A R T I C L E I N F O}

\section{Keywords:}

Paleodiet

Stable isotopes

Radiocarbon

Rural communities

Middle age

Northern Iberia

\begin{abstract}
A B S T R A C T
A medieval osteological sample $(n=20)$ from the isolated rural community of San Baudelio de Berlanga (Soria, $\mathrm{N}$-Spain) was studied using paleopathological and stable isotope analyses. The necropolis was initially dated by archeologists between the XI and XII centuries AD and contains 57 individuals. The main objective of this study was to investigate the diet and the chronology of these individuals to improve the understanding not only of the diet but also of the population dynamics in an isolated rural site. The isotopic composition of their rib bone collagen was determined. $\delta^{15} \mathrm{~N}$ values ranged between $9.3 \%$ and $11.5 \%$, with a mean of $10.3+0.5 \%$ (AIR), while $\delta^{13} \mathrm{C}$ values ranged between $-17.6 \%$ and $-19.0 \%$ with a mean of $-18.2+0.4 \%$ (V-PDB). Radiocarbon results dated the individuals to between the XI and mid-XIII century. The stable isotopic results suggest a mixed terrestrial diet dominated by $\mathrm{C}_{3}$ cereals but including also animal products (e.g. meat and dairy products). Isotopic differences between sexes may be related more closely to social (patrilineal pattern of pairing) and biodemographical (lower female life expectancy) factors than dietary gender differences.
\end{abstract}

\section{Introduction}

Over the past few years a number of research projects using stable isotopes to explore the settlements of North Iberia have been undertaken. Their aim is not only to determine the diet of these populations but also to increase knowledge on settlement patterns, landscape transformations, agricultural practices, population movements, social dynamics, and living conditions (e.g., García-Collado, 2016; Guede et al., 2017; Lubritto et al., 2013, 2017; Mundee, 2009, 2010; Ortega et al., 2012; Quirós Castillo, 2011, 2013; Quirós Castillo et al., 2013, etc.).

\subsection{The site of San Baudelio de Berlanga}

Anthropological studies have been published on a collection of medieval human remains from the rural setting of San Baudelio de Berlanga (Soria Province) in the North of the Iberian Peninsula (Guerrero et al., 2003; Maroto, 2004; Castillo González, 2008; Al Oumaoui, 2009), but until now no dietary research has been undertaken. This area of Soria Province served as a settlement for hermits and monks of Visigothic rite and became populated after the fall of the caliphate of Cordoba with people from North of the Duero and with Mozarabs escaping from the South during the XI and XII centuries (Andrío and Loyola, 1992). Little written evidence is available on San Baudelio de Berlanga, although it is known to have been dominated by Muslims during some periods of the XI century until it passed definitively into Christian hands after the conquest of these lands by Alfonso VI of Castile (1065-1109 CE) (García de Cortázar, 1995; Escolano, 2003). The inhabitants of these rough lands would have been peasants living under harsh conditions in a feudal agrarian economy (Banks et al., 1983).

San Baudelio de Berlanga is famous for its XI century hermitage belonging to a monastery of Visigothic rite, which features XII century frescoes considered jewels of European Medieval Art (Guardia, 2011). Monasteries of Visigothic rite were sited in secluded places far from populated areas (Díaz Martínez, 1988). When the Cluniac monastic order spread throughout Castile at the end of the XII century, the monks abandoned San Baudelio, which became an isolated farm (Banks et al., 1983). The foundation of the monastery could not have preceded 1010 , which is when Alfonso VI of Castile took control the area (Escolano,

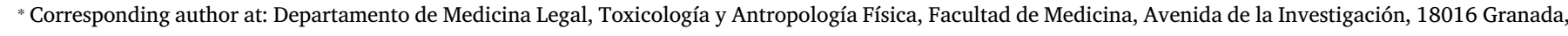
Spain.

E-mail addresses: jbrobeil@ugr.es (S.A. Jiménez-Brobeil),rmmaroto@ugr.es (R.M. Maroto), laffranchi@ugr.es (Z. Laffranchi), mgroca@gmail.com (M.G. Roca), arseniog@iact.ugr-csic.es (A. Granados Torres), antonio.delgado@csic.es (A. Delgado Huertas).
} 


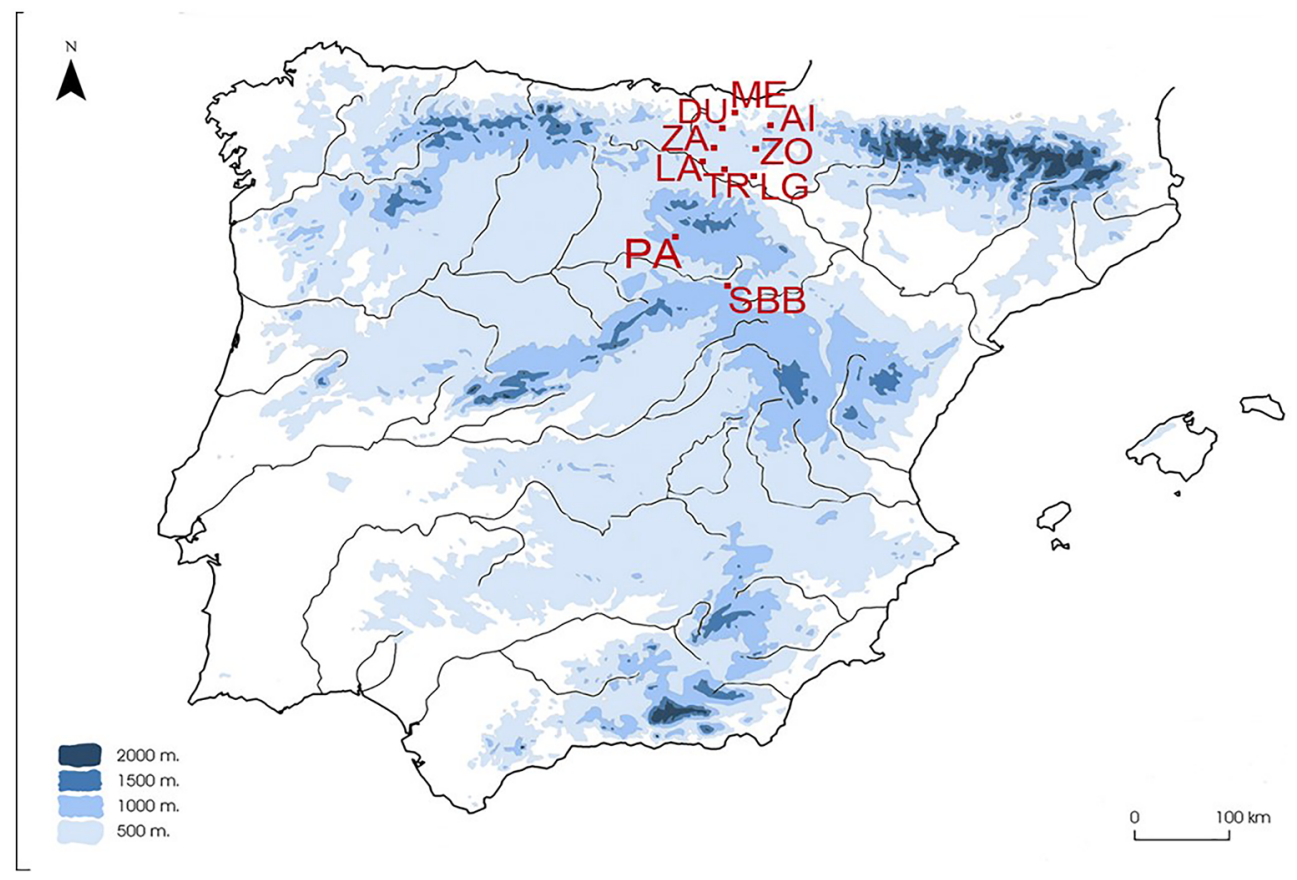

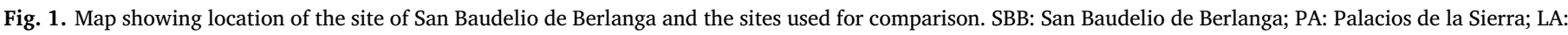
San Martín de Lantarón; ZA: Zaballa; TR: Treviño; LG: Las Gobas; DU: Dulantzi; ZO: Zornoztegi; ME: Mendraka; 10: Aistra.

2003, Guardia, 2011). In 1136, there is a written reference to the monastery when it was under the bishopric of Sigüenza (... Berlangam cum ómnibus terminis suis et cum monasterio sancti Baudili:"Berlanga with all their landings and with the San Baudelio monastery"). The last reference to the monastery as such appears in 1144 (... monasterium sancti Bauduli, quod circa Berlangam situm est...: "the San Baudelio monastery which is near Berlanga"), given that later writings only use the term domus, i.e. farm (Escolano, 2003; Guardia, 2011).

San Baudelio is situated around nine kilometers from Berlanga de Duero in the Southeast of Soria Province at 1049 m above sea level (Fig. 1).

The geographical location and characteristics of San Baudelio are similar to those of sites in the Upper Arlanza basin / Upper Duero basin corridor, whose eastern end is $50 \mathrm{kms}$ away, at an altitude of 1000-1200 m above sea level (Padilla and Álvaro, 2008, 2013). According to studies on the medieval landscape in this area (Padilla and Álvaro, 2010, 2013), San Baudelio could be defined as a minor settlement around a cult center whose ecclesiastical building agglutinate the cemetery. The climate in San Baudelio is classified as Cfb (C: medium latitude; f: no dry season; b: cold or temperate winters and cool summers) according to the Köppen system (AEMET, 2011). The altitude of San Baudelio, with occasional springtime freezing, is suitable for keeping livestock or hunting but is not favorable for growing crops (Banks et al., 1983). These features are shared by sites in the Upper Arlanza/Upper Duero, where climatic conditions are typical of mountain areas and impose major constraints on the development of agriculture, favoring the exploitation of livestock and forest resources (López Pérez et al., 2016; Padilla and Álvaro, 2010, 2013). The isolation of the hermitage, the disappearance of the monastery, and the climatic worsening of the Little Ice Age would explain the abandonment of the farm allowing preservation of the hermitage and its frescoes.

\subsection{The necropolis}

A small necropolis placed against the wall of the apse of San Baudelio de Berlanga hermitage contains tombs dated to the XII century by Castillo (1972), at a time when the hermitage frescoes were created and Alfonso I of Aragón was repopulating the area. These were not the tombs of Visigothic monks or hermits but rather of the inhabitants of a small rural nucleus or farm (Vigil-Escalera, 2007), including families who worked for the monastery. Unlike other medieval Castilian necropolis with preserved skeletal remains, such as Palacios de la Sierra or Villanueva de Soportilla (Castillo, 1972), the San Baudelio cemetery does not belong to a small village or a town but rather to a farm in which only a few families would live (Banks et al., 1983). Castillo (1972) observed several types of tomb, defined as anthropomorphic, oval and "bathtub", which he considered to be from different time periods, although other medievalists do not consider it possible to establish a chronology based on tomb typology and insist on the need for absolute dating (Martín Viso, 2007, 2012, 2014; Hernández Barreña et al., 2013; López Pérez et al., 2016). In the San Baudelio necropolis, tombs are oriented West-East and covered with labs of rock (Fig. 2). Tombs of anthropomorphic shape alternate with those of rectangular "bathtub" type, in which the individual is placed in supine position in accordance with Christian tradition (Andrío and Loyola, 1992; Escolano, 2003). Although separate spaces were cut into the rock as individual tombs, several of them were reutilized as family vaults. Alberto del Castillo reported a total of 19tombs, most of which were collective, with one of them containing the remains of no fewer than eight individuals. No animal bones have been associated with the tombs.

\subsection{The population}

Out of the total remains of 57 skeletons, $24.6 \%$ belong to children under 7 years old. The life expectancy was very low. In general, little difference was found among the studied individuals in skeletal markers related to physical activity, which generally indicate a moderate to strong development of entheseal changes, especially in the lower limbs. These skeletal markers are consistent with a population of peasant farm workers who appear to have engaged in intense physical activity, with signs of osteoarthritis and the presence of Schmorl's nodes in young adult males and cases of spondylolysis with spondylolisthesis in both sexes, as well as numerous traumatic injuries (see $\mathrm{Al}$ Oumaoui et al., 2004; Guerrero et al., 2003). 


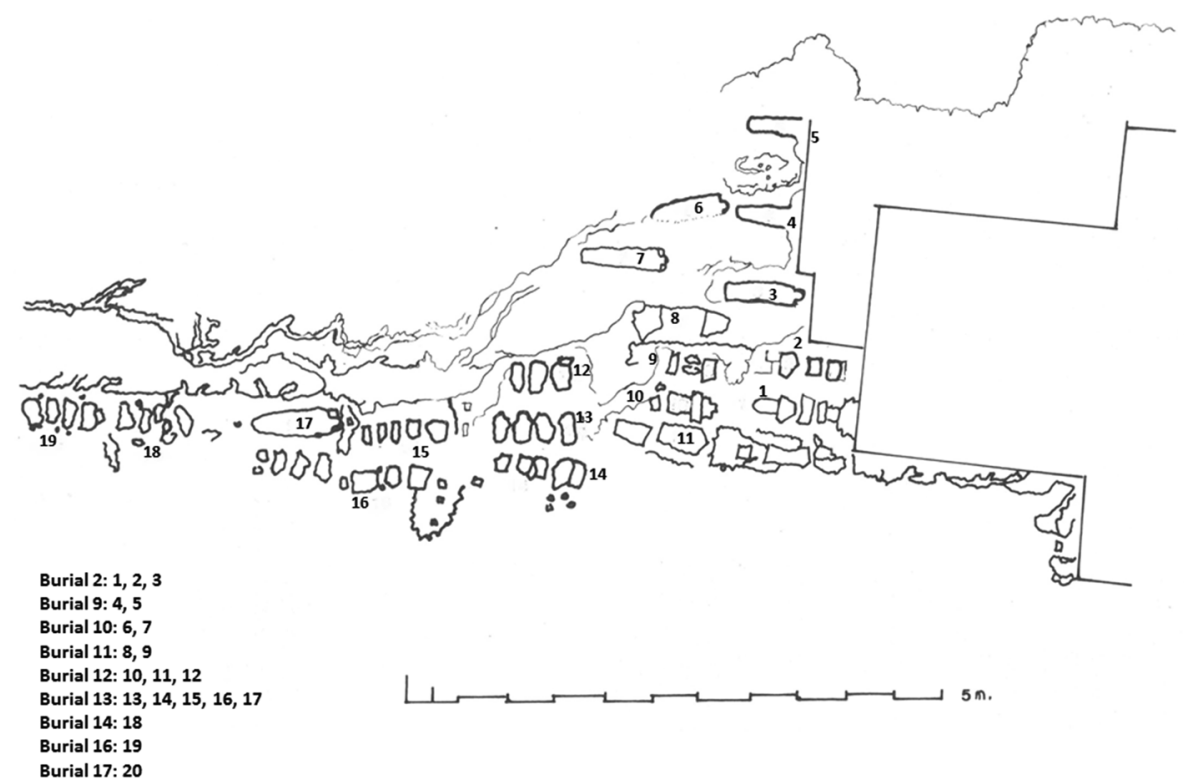

Fig. 2. Plan of tombs alongside the hermitage, indicating the location of the 20 individuals analyzed in this study.

\subsection{Dietary reconstruction}

Various methods are available to bioarcheologists for dietary reconstruction like analysis of plant and animal remains, coprolites, pottery residues, trace elements, or stable isotopes (Larsen, 2015). Other methods coming from teeth, like analysis of dental pathology, microwear, or calculus (Hardy et al., 2009; Powell, 1985; Romero and De Juan, 2007; Salazar-García et al., 2016). In the present investigation, we used the study of maxillodental disease and stable isotope analysis that are complementary (Bonsall and Pickard, 2015). Diet is one of the main factors related to maxillodental disease, with the consumption of refined carbohydrates being closely linked to caries development (Powell, 1985). However, milk and cheese offer a protective factor against caries (Bowen and Pearson, 1993), and very low rates of caries have been recorded in populations with almost wholly carnivorous diets (such as the Inuit or Sioux) (Costa, 1980; Powell, 1985).

The most frequent approach in stable isotope studies is to determine carbon $\left(\delta^{13} \mathrm{C}\right)$ and nitrogen $\left(\delta^{15} \mathrm{~N}\right)$ ratios in bone collagen. Carbon isotope values reflect the proportions of $\mathrm{C}_{3}$ and $\mathrm{C}_{4}$ plants in the diet and yield information on environmental parameters (DeNiro and Epstein, 1978; Fernandes et al., 2012; Katzenberg, 2000; Schoeninger and Moore, 1992). $C_{3}$ and $C_{4}$ plant biomasses differ in $\delta^{13} \mathrm{C}$ values because of their specific photosynthetic pathways. Thus, $\mathrm{C}_{3}$ plants (e.g. wheat, barley, rice etc.) are generally enriched in ${ }^{12} \mathrm{C}$ and have more negative $\delta^{13} \mathrm{C}$ values (about $-24 /-36 \%$ ), whereas $\mathrm{C}_{4}$ plants (e.g. sorghum, millet) are not ${ }^{12} \mathrm{C}$ enriched and are characterized by less negative $\delta^{13} \mathrm{C}$ values (about-12.5\%) (Honch et al., 2012; Katzenberg, 2000; Laffranchi et al., 2016; Schoeninger and Moore, 1992).

Nitrogen isotope values determine the position in the trophic chain of herbivores and carnivores and may provide clues about the intake of animal protein (DeNiro and Epstein, 1981; Hedges and Reynard, 2007; O'Connell et al., 2012; Schoeninger, 1985). The combined study of these isotopes yields information on the consumption of terrestrial or marine resources (Herrscher et al., 2018; Schoeninger et al., 1983; Schoeninger and DeNiro, 1984; Larsen, 2015).

There are several isotopic studies on medieval populations in the North of Iberia, which are mainly rural and of Christian religion. In those located next to the sea, the values clearly demonstrate the consumption of marine resources. Inland there is a clear consumption of $\mathrm{C}_{3}$ plants although in some sites, in environments regarded as poorer, millet, a $\mathrm{C}_{4}$ plant, must have been part of the diet. Regarding nitrogen values, there is a great variability that has been attributed to social differences. Usually there are no differences between the type of products consumed by men and women (García-Collado, 2016; Guede et al., 2017; Lubritto et al., 2017).

The main objective of this study was to use isotopic analysis and the study of maxillodental pathology to obtain data on the diet of individuals buried in this necropolis, providing knowledge not only on their food sources but also on the settling of the region and the social dynamics of a isolated rural nucleus, comparing results with findings in larger rural settlements of the Northern Iberian Peninsula. Secondary objectives were to establish the time periods in which the necropolis was used through the absolute dating of some of the skeletons, and to examine any evidence of socioeconomic changes.

\section{Material and methods}

\subsection{Human and animal remains}

The study sample was selected from among the 57 individuals in the San Baudelio de Berlanga collection housed in the Physical Anthropology Laboratory of the University of Granada (Maroto, 2004; Castillo González, 2008). The degree of preservation is generally good, although some individuals come from tombs that had been reutilized multiple times, making their study more challenging. In the present investigation, we only studied individuals clearly identified as distinct groups of bones in the archaeological excavation and who met the following criteria: adult age, possibility of establishing the age and sex, preservation of at least $75 \%$ of dental arches, and certainty that all bones came from a single skeleton. Previously reported sex and age data (Maroto, 2004) were confirmed by morphological study of pelvis and skull and examination of pubic symphysis, sternal ribs, and cranial sutures, as described by numerous authors (Byers, 2005; Ferembach et al., 1979).

The preservation of dental arches is necessary for the study of dental disease, a classic method to explore ancient diets (Powell, 1985). Presence of caries, ante mortem losses, apical cysts, and periodontal disease were recorded according to sex and age following Hillson (1996). Results are expressed in terms of teeth and sockets to facilitate comparisons with other studies and because of the small number of individuals studied.

Rib samples were only selected for isotopic analysis from the 20 individuals (13 males, 7 females) who were more complete and clearly anthropologically individualized: 8 males aged 20-40 years (young 
Table 1

${ }^{14} \mathrm{C}$ dating of the selected individuals calibrated with Oxcal 4.3.2 program and IntCal13 atmospheric curve (Bronk Ramsey, 2017; Reimer et al., 2013).

\begin{tabular}{|c|c|c|c|c|c|}
\hline Sample & Lab. code & $\delta^{13} \mathrm{C}$ & ${ }^{14} \mathrm{C}$ Age & 1бcal AD 68\% & $2 \sigma c a l \mathrm{AD} 95 \%$ \\
\hline SBB-8 & CNA-4589 & $-18.87 \%$ & $920 \pm 30$ & $1045-1157$ & $1028-1184$ \\
\hline SBB-11 & CNA-4325 & $-19.11 \%$ & $930 \pm 30$ & 1041-1154 & 1025-1165 \\
\hline SBB-16 & CNA-4326 & $-18.99 \%$ & $930 \pm 30$ & $1041-1154$ & $1025-1165$ \\
\hline SBB-18 & CNA-4327 & $-19.86 \%$ & $890 \pm 30$ & $1050-1206$ & $1041-1218$ \\
\hline SBB-20 & CNA-4328 & $-20.20 \%$ & $850 \pm 30$ & $1163-1221$ & $1052-1260$ \\
\hline
\end{tabular}

adults) and 5 males aged 41-60 years (mature); and 7 females aged under 30 years.

Animal isotopic data are essential to establish local isotopic baselines from which to reconstruct human dietary variations in time and space (Goude and Fontugne, 2016; Bownes et al., 2018). For this purpose, we also analyzed 11 samples from animals found at the medieval site of San Martín de Lantarón (Quirós Castillo, 2014), which has the same climate (Cfb in Köppen system) as San Baudelio (AEMET, 2011), although difficulties in the comparison of soils mean that results should be interpreted with caution (Bownes et al., 2018).

\subsection{Collagen extraction, stable isotope analyses and chronology}

The isotopic study was conducted in 20 rib samples with no fracture callus or signs of infection (Olsen et al., 2014). Ribs were chosen due to their number in the skeleton, thereby limiting impact on the damage to the individual and for their collagen turnover rate (Hill, 1998). The analyses were performed following the protocol described by Bocherens et al. (1997) (Bocherens and Drucker, 2003) in the Biogeochemistry Department of the Andalusian Institute of Earth Sciences (CSIC) Stable Isotopes Laboratory. Rib samples were powdered in a mortar, and $300 \mathrm{mg}$ of the powder was decalcified in $1 \mathrm{M} \mathrm{HCl}$ for $20 \mathrm{~min}$ at room temperature, eliminating phosphates, fulvic acids and other soluble acids, and was then passed through a MF-Millipore $5 \mu \mathrm{m}$ filter. The insoluble residue was plunged into $0.125 \mathrm{M}$ of $\mathrm{NaOH}$ for $20 \mathrm{~h}$ at room temperature. After rinsing with Milli-Q water, the neutralized sample was again filtered $(5 \mu \mathrm{m})$ to remove humic acids and most lipids; this residue was plunged into $10-2 \mathrm{M} \mathrm{HCl}(\mathrm{pH} 2)$ solution in closed pyrex tubes at $100^{\circ}$ to solubilize the collagen. After centrifugation, the supernatant was lyophilized and analyzed for its isotopic composition. The collagen samples obtained were treated in a continuous flow system using an elemental analyzer connected to a mass spectrometer. Sample combustion was obtained at $1020{ }^{\circ} \mathrm{C}$, producing a mixture of carbon and nitrogen oxides that was then reduced at $650{ }^{\circ} \mathrm{C}$, obtaining a mixture of $\mathrm{CO}_{2}, \mathrm{~N}_{2}$, and $\mathrm{H}_{2} \mathrm{O}$. The water was chemically removed, and $\mathrm{CO}_{2}$ and $\mathrm{N}_{2}$ were separated using a chromatographic column before mass spectrometry analysis. An elemental analyzer (Carlo Erba Model
NA1500 NC series 2) was used for the combustion, reduction, water removal, and chromatographic separation processes. The $\mathrm{N}_{2}$ and $\mathrm{CO}_{2}$ obtained by these procedures were introduced into a Delta Plus XL mass spectrometer for isotope analysis. The analytical error for $\delta^{15} \mathrm{~N}$ and $\delta^{13} \mathrm{C}$ determinations was $<0.1 \%$.

Isotope results are always expressed in relation to a universally accepted international reference pattern: V-PDB for carbon and AIR for nitrogen (Coplen, 1995). Only samples with good collagen quality were considered, with atomic C:N ratios between 2.9 and 3.6 (DeNiro, 1985), high carbon and nitrogen concentrations (Ambrose, 1990), and collagen yield of at least 1\% (van Klinken, 1999).

Five of the individuals with the best-preserved collagen ( 2 females and 3 males) were selected for radiocarbon dating, including two of particular pathological interest (one with trepanation and one with traumatic lesion), sending the five collagen samples to the National Accelerator Center (Spanish initials, CNA) in Seville. CNA uses the Micadas system (Mini Carbon Dating System), based in the AMS technique (Accelerator Mass Spectrometry). The results were elaborated with the Oxcal 4.3.2 calibration program and the IntCal13 atmospheric curve (Bronk Ramsey, 2017; Reimer et al., 2013).

\subsection{Statistical procedure}

The non-parametric Mann-Whitney $U$ test was used for betweengroup comparisons because of the small sample size. Potential outliers were identified by standard deviation approach ( $\pm 2 \mathrm{SD}$ ), and Tukey's method $(1.5 \times$ interquartile range). The chi-square test was used to compare maxilla dental results, expressed in percentages. $\mathrm{P} \leq 0.05$ was considered significant in all tests. SPSS version 21 (IBM SPSS, Chicago, IL) was used for the statistical analyses.

\section{Results}

\subsection{Radiocarbon dating}

Table 1 and Fig. 3 exhibit results obtained from the five samples. Three were dated between XI and XII centuries (SBB-8, SBB-11 and SBB16 ) and two between XI and XIII centuries (SBB-18 and SBB-20) with a probability of $95 \%$. The sex and age of these individuals are reported in table 2.

\subsection{Isotopic results}

Table 2 displays the data obtained for each individual. All samples passed collagen quality criteria. $\delta^{15} \mathrm{~N}$ values ranged between $9.3 \%$ and $11.5 \%$, with a mean of $10.3 \pm 0.5 \%$, and $\delta^{13} \mathrm{C}$ values ranged between $-17.6 \%$ and $-19.0 \%$, with a mean of $-18.2 \pm 0.4 \%$. Table 3 exhibits carbon and nitrogen isotope results in the animals from San

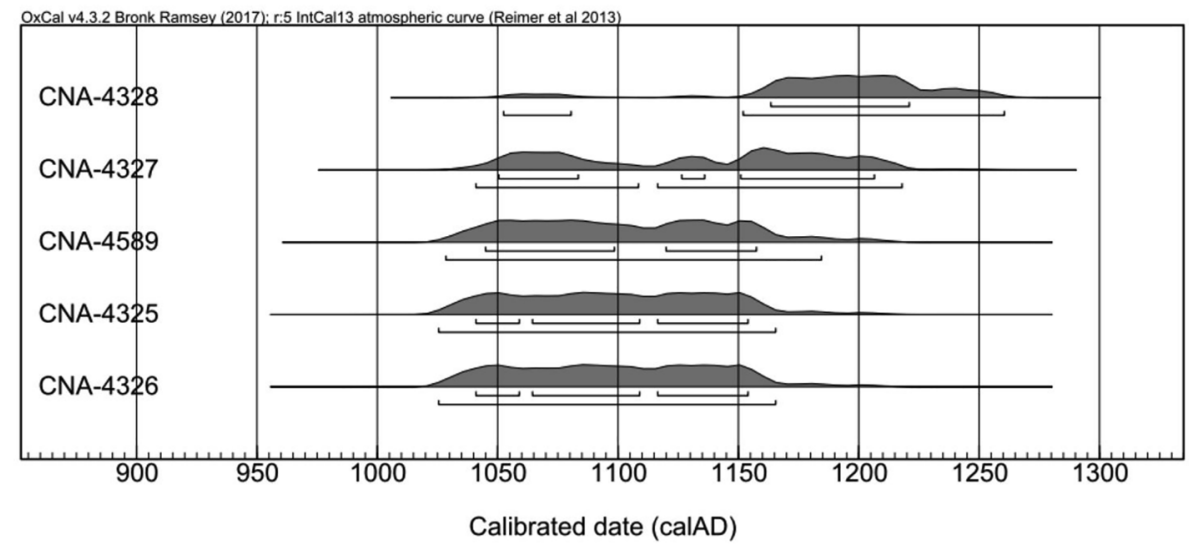

Fig. 3. Radiocarbon dating of samples from San Baudelio de Berlanga. 
Table 2

Carbon and nitrogen isotope results in humans and collagen quality criteria.

\begin{tabular}{|c|c|c|c|c|c|c|c|c|c|c|c|}
\hline Sample & Burial & Indi-vidual & Bone & Sex & Age & $\delta^{15} \mathrm{~N} \% 0$ & $\delta^{13} \mathrm{C} \%$ & $\% \mathrm{~N}$ & $\% \mathrm{C}$ & $\mathrm{C}: \mathrm{N}$ & $\%$ coll. yield \\
\hline SBB-1 & 1 & $\mathrm{H}$ & rib & $\mathrm{F}$ & $\mathrm{Ya}$ & 10.1 & -18.0 & 15.7 & 41.5 & 3.1 & 14.5 \\
\hline SBB-2 & 1 & A & rib & M & Ma & 10.2 & -18.2 & 15.8 & 41.5 & 3.0 & 10.3 \\
\hline SBB-3 & 1 & $\mathrm{~B}$ & rib & M & Ma & 9.6 & -18.0 & 15.6 & 41.5 & 3.1 & 14.2 \\
\hline SBB-4 & 9 & 2 & rib & $\mathrm{F}$ & Ya & 10.1 & -17.9 & 15.9 & 41.8 & 3.0 & 10.1 \\
\hline SBB-5 & 9 & 1 & $\mathrm{rib}$ & $\mathrm{F}$ & Ya & 10.0 & -17.8 & 16.0 & 41.9 & 3.0 & 12.8 \\
\hline SBB-6 & 10 & 1 & rib & $\mathrm{F}$ & $\mathrm{Ya}$ & 9.2 & -18.0 & 15.9 & 41.4 & 3.0 & 11.4 \\
\hline SBB-7 & 10 & 2 & $\mathrm{rib}$ & M & Ya & 10.1 & -18.0 & 15.8 & 41.3 & 3.0 & 11.9 \\
\hline SBB-8 & 11 & 1 & $\mathrm{rib}$ & $\mathrm{F}$ & Ya & 10.9 & -18.0 & 16.0 & 41.3 & 3.0 & 15.0 \\
\hline SBB-9 & 11 & 2 & rib & M & Ma & 10.9 & -18.7 & 15.5 & 41.7 & 3.1 & 14.6 \\
\hline SBB-10 & 12 & 2 & rib & M & $\mathrm{Ya}$ & 10.4 & -18.9 & 15.7 & 41.5 & 3.1 & 11.7 \\
\hline SBB-11 & 12 & 3 & rib & M & $\mathrm{Ya}$ & 10.5 & -18.5 & 15.7 & 41.8 & 3.1 & 10.3 \\
\hline SBB-12 & 12 & 4 & rib & M & Ya & 10.5 & -18.3 & 15.4 & 40.6 & 3.1 & 9.4 \\
\hline SBB-13 & 13 & 5 & rib & M & Ma & 9.9 & -18.4 & 15.2 & 40.6 & 3.1 & 13.6 \\
\hline SBB-14 & 13 & A & rib & $\mathrm{F}$ & $\mathrm{Ya}$ & 9.8 & -18.1 & 15.8 & 41.7 & 3.0 & 14.6 \\
\hline SBB-15 & 13 & $\mathrm{C}$ & rib & M & $\mathrm{Ya}$ & 11.2 & -18.3 & 15.9 & 41.7 & 3.0 & 8.5 \\
\hline SBB-16 & 13 & $\mathrm{D}$ & rib & M & $\mathrm{Ya}$ & 11.5 & -19.0 & 15.9 & 41.8 & 3.0 & 13.6 \\
\hline SBB-17 & 13 & $\mathrm{E}$ & rib & M & $\mathrm{Ya}$ & 10.4 & -18.0 & 16.2 & 41.7 & 2.9 & 11.3 \\
\hline SBB-18 & 14 & & rib & $\mathrm{F}$ & $\mathrm{Ya}$ & 9.8 & -17.6 & 15.9 & 41.3 & 3.0 & 10.9 \\
\hline SBB-19 & 16 & 2 & rib & M & Ma & 10.1 & -18.0 & 15.6 & 41.5 & 3.1 & 12.7 \\
\hline SBB-20 & 17 & & rib & M & $\mathrm{Ya}$ & 10.0 & -17.5 & 15.7 & 41.4 & 3.0 & 9.7 \\
\hline
\end{tabular}

M: males; F: females; Ya: young adults; Ma: mature adults.

Table 3

Carbon and nitrogen isotope results in animals from San Martín de Lantarón and collagen quality criteria.

\begin{tabular}{llllllll}
\hline Sample & Species & $\delta^{15} \mathrm{~N} \%$ & $\delta^{13} \mathrm{C} \%$ & $\% \mathrm{~N}$ & $\% \mathrm{C}$ & $\mathrm{C}: \mathrm{N}$ & $\%$ coll. yield \\
\hline LA-1 & Ovicaprid & 3.3 & -21.0 & 14.4 & 40.7 & 3.3 & 1.7 \\
LA-2 & Suid & 5.2 & -19.9 & 14.2 & 40.9 & 3.3 & 4.5 \\
LA-3 & Suid & 6.5 & -20.3 & 14.5 & 40.6 & 3.3 & 7.2 \\
LA-4 & Ovicaprid & 6.8 & -15.6 & 14.3 & 40.8 & 2.9 & 3.2 \\
LA-5 & Bovid & 6.6 & -20.4 & 14.5 & 40.7 & 3.4 & 11.2 \\
LA-6 & Bovid & 6.8 & -19.9 & 14.6 & 40.6 & 3.3 & 4.3 \\
LA-7 & Bovid & 6.5 & -20.6 & 14.4 & 40.7 & 3.2 & 8.1 \\
LA-8 & Bovid & 4.9 & -20.9 & 14.5 & 40.6 & 3.5 & 6.4 \\
LA-9 & Ovicaprid & 6.8 & -19.1 & 14.6 & 40.6 & 3.3 & 6.5 \\
LA-10 & Ovicaprid & 4.9 & -21.1 & 14.4 & 40.7 & 3.5 & 5.1 \\
LA-11 & Ovicaprid & 7.3 & -20.8 & 14.6 & 40.5 & 3.4 & 4.3 \\
\hline
\end{tabular}

Martín de Lantarón, divided by species. Table 4 displays mean values of the individuals by sex and age and mean values reported in fauna from San Martín de Lantarón. Figs. 4 and 5 show that the $\delta^{13} \mathrm{C}$ values were significantly higher and less widespread among the females than among the males ( $\mathrm{p}=0.024$, Mann-Whitney $U$ test). Figs. 4 and 5 show that higher $\delta^{15} \mathrm{~N}$ values were observed in the males than in the females, although the difference was only close to significance $(\mathrm{p}=0.081$, Mann-Whitney $U$ test). The only statistically significant result obtained when age groups were compared by sex was higher $\delta^{15} \mathrm{~N}$ values in young adult males than in young adult females $(\mathrm{p}=0.031$, MannWhitney $U$ test).
When the standard deviation approach ( \pm 2SD) was used, the sole outliers were for $\delta^{13} \mathrm{C}$ in female SBB-18 and $\delta^{15} \mathrm{~N}$ in the male SBB-16. Application of the Tukey test (1.5XIQR) identified the $\delta^{15} \mathrm{~N}$ of the females SBB- 6 and SBB-8 as outliers. The aforementioned values for SBB18 and SBB-16 were one decimal point from reaching the value of the interquartile interval.

With regard to possible social differences, it should be borne in mind that the elevated consumption of animal proteins was typical of medieval elites (Kjellström et al., 2009; Jiménez-Brobeil et al., 2016). The males SBB-9, SBB-15, and SBB-16 and the female SBB- 8 have high $\delta^{15} \mathrm{~N}$ values. SBB-8 and SBB-9 were buried together in one tomb, and SBB-15 and SBB-16 in another.

\subsection{Maxillodental disease}

Table 5 displays the maxillodental findings as a function of sex and age. As expected, the frequency of maxillodental disease (caries, ante mortem losses and total damaged teeth) was much higher in the mature adult males than in the younger adults, attributable to their longer exposure to wear and oral cavity bacteria (Hillson, 1996).

Highly significant differences were found between the age groups $(\mathrm{P}<0.001)$. Males were generally much more severely affected by dental disease in comparison to the females $(\mathrm{P}<0.001)$, although this is related to the absence of mature females. No significant difference in total damaged teeth (caries + ante mortem losses) was found between young adult males and young adult females $(\mathrm{P}=0.74)$.

Table 4

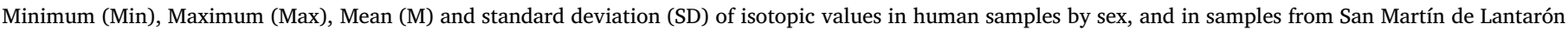
(LA) by species.

\begin{tabular}{|c|c|c|c|c|c|c|c|c|c|c|}
\hline & \multicolumn{5}{|c|}{$\delta^{15} \mathrm{~N} \%$ (AIR) } & \multicolumn{5}{|c|}{$\delta^{13} \mathrm{C} \% 0(\mathrm{~V}-\mathrm{PDB})$} \\
\hline & $\mathrm{N}$ & Min & $\operatorname{Max}$ & M & SD & $\mathrm{N}$ & Min & Max & M & SD \\
\hline SBB Young females & 7 & 9.3 & 10.9 & 10.0 & 0.5 & 7 & -18.1 & -17.6 & -17.9 & 0.2 \\
\hline SBB Males (total) & 13 & 9.6 & 11.5 & 10.4 & 0.5 & 13 & -19.0 & -17.5 & -18.3 & 0.4 \\
\hline SBB Young males & 8 & 10.1 & 11.5 & 10.6 & 0.5 & 8 & -19.0 & -17.5 & -18.3 & 0.5 \\
\hline SBB Mature males & 5 & 9.6 & 10.9 & 10.1 & 0.5 & 5 & -18.7 & -18.0 & -18.3 & 0.3 \\
\hline SBB Total & 20 & 9.3 & 11.5 & 10.3 & 0.5 & 20 & -19.0 & -17.6 & -18.2 & 0.4 \\
\hline LA Bovid & 4 & 4.8 & 6.9 & 6.2 & 0.9 & 4 & -20.9 & -19.9 & -20.4 & 0.4 \\
\hline LA Suid & 2 & 5.2 & 6.5 & 5.9 & & 2 & -20.3 & -19.9 & -20.1 & \\
\hline LA Ovicaprid & 5 & 3.3 & 7.3 & 5.8 & 1.7 & 5 & -21.1 & -19.1 & -20.3 & 0.9 \\
\hline
\end{tabular}




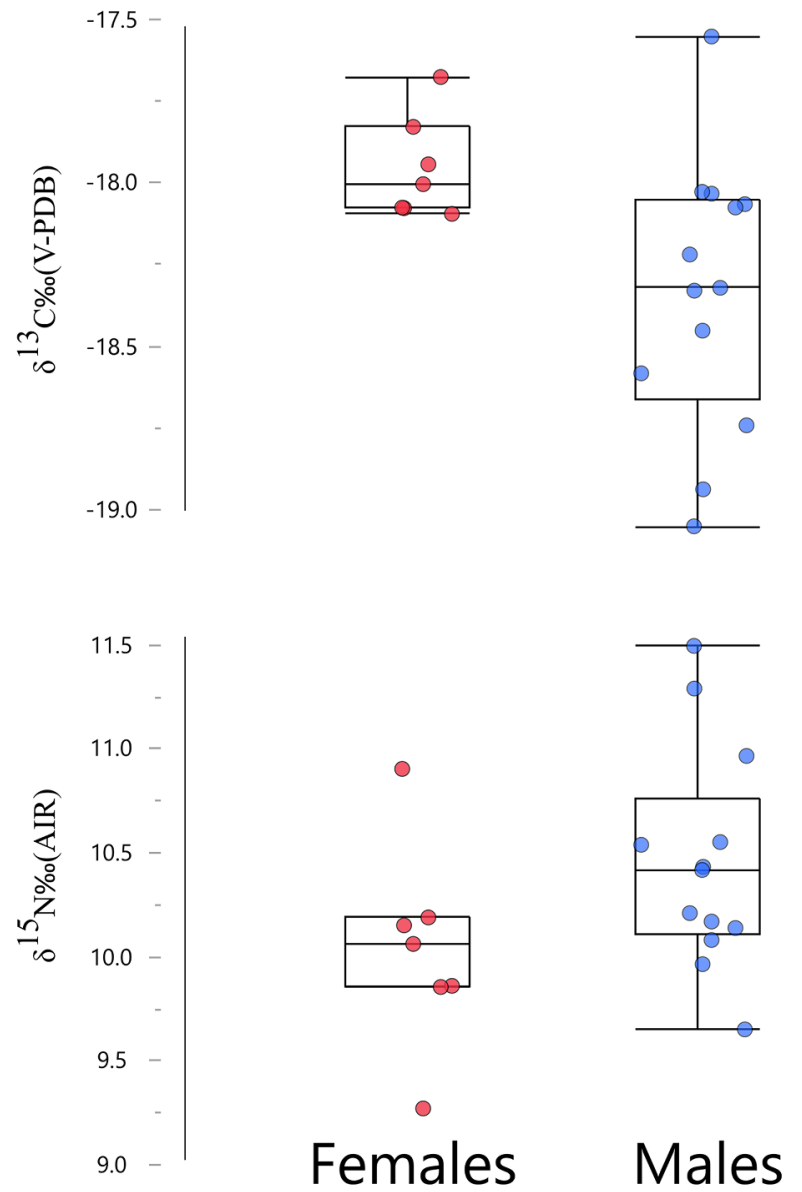

Fig. 4. $\delta^{13} \mathrm{C}$ and $\delta^{15} \mathrm{~N}$ values for SBB females (in red) and males (in blue).

\section{Discussion}

No written sources are available on the construction and utilization dates of the necropolis at San Baudelio, and the present radiocarbon dating results refer, like says Martín Viso (2014), to the skeletons rather than the tombs. Based on stylistic criteria, medieval art specialists have concluded that the hermitage was constructed in the XI century and that the frescoes were produced in the XII century (Escolano, 2003;

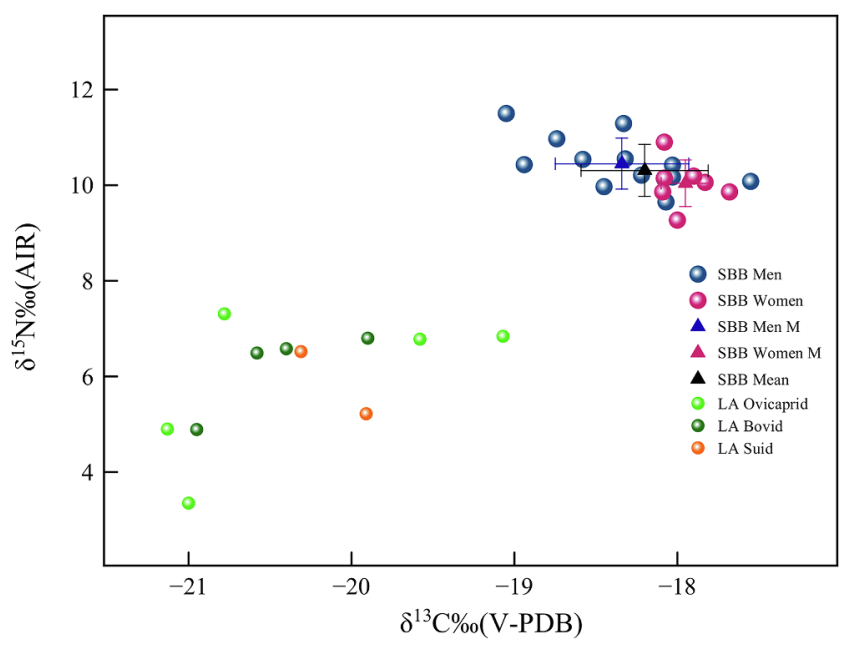

Fig 5. Scatterplot of $\delta^{13} \mathrm{C}$ and $\delta^{15} \mathrm{~N}$ values for individuals from SBB (red for female and blue for male) and values for faunal remains from San Martín de Lantarón (ovicaprid, bovid and suid).
Table 5

Maxillodental results by sex and age. YA: young adults (aged 20-40 years), MA: mature adults (41-60 years). N: number of pieces or alveoli. \%: Percentage involvement (teeth with caries $\times 100 /$ total teeth; ante mortem losses $\times 100$ / total alveoli; total damaged teeth $\times 100 /$ total alveoli).

\begin{tabular}{|c|c|c|c|c|}
\hline & \multicolumn{2}{|c|}{ Males } & \multicolumn{2}{|c|}{ Females } \\
\hline & $\mathrm{N}$ & $\%$ & $\mathrm{~N}$ & $\%$ \\
\hline Teeth YA & 159 & & 101 & \\
\hline Teeth MA & 70 & & - & \\
\hline Alveoli YA & 235 & & 207 & \\
\hline Alveoli MA & 125 & & - & \\
\hline Total teeth & 229 & & 101 & \\
\hline Total alveoli & 360 & & 207 & \\
\hline Caries YA & 7 & 4.4 & 2 & 1.9 \\
\hline Caries MA & 9 & 12.8 & - & \\
\hline Total caries & 16 & 6.9 & 2 & 1.9 \\
\hline Ante mortem losses YA & 18 & 7.6 & 18 & 8.7 \\
\hline Ante mortem losses MA & 32 & 25.6 & - & \\
\hline Total ante mortem losses & 50 & 13.9 & 18 & 8.7 \\
\hline Total damaged teeth YA & 25 & 10.6 & 20 & 9.7 \\
\hline Total damaged teeth MA & 41 & 32.8 & - & \\
\hline Total damaged teeth & 66 & 18.3 & 20 & 9.7 \\
\hline
\end{tabular}

Guardia, 2011). It was not possible to obtain direct absolute dating information on the frescoes, but the dates obtained for individuals in the necropolis suggest that it was used from the beginning of the XI century to middle of the XIII century. These dates are consistent with the above estimations, and the scant documentary references available (Escolano, 2003; Guardia, 2011). These findings make a major contribution to the archeology of the cemeteries (Padilla and Álvaro, 2010; López Pérez et al., 2016) and the history of the medieval art of Castile, for which scant data are available to date. Interestingly several Upper Arlanza/Upper Duero sites were also depopulated in the middle of the 13th century (Padilla and Álvaro, 2008, 2010, López Pérez et al., 2016), during the transition between the Medieval Climate Anomaly and the Little Ice Age (Moreno et al., 2012).

Isotopic values of animals from San Martin de Lantarón, showed very negative $\delta^{13} \mathrm{C}$ values, denoting a type $\mathrm{C}_{3}$ plant-based diet (DeNiro and Epstein, 1978). Results of comparisons between the humans in San Baudelio de Berlanga and animals from the site of San Martín de Lantarón ( $\Delta 13 \mathrm{C}$ human-fauna $=2.1 \% ; \Delta 15 \mathrm{~N}$ human-fauna $=4.4 \%$ ), especially the carbon delta value difference, are consistent with data in the literature on the trophic chain (DeNiro and Epstein, 1981; Hedges and Reynard, 2007; Minagawa and Wada, 1984; O'Connell et al., 2012). Thus, the stable isotope study revealed that the individuals buried in San Baudelio had a mixed terrestrial diet (meat, eggs, or dairy products and vegetal foodstuffs) with land plants, largely type $\mathrm{C}_{3}$.

The finding of higher $\delta^{15} \mathrm{~N}$ and less negative $\delta^{13} \mathrm{C}$ values in the males of San Baudelio is in line with results in other populations and may indicate preferential access by males to the most highly valued resources (Choy et al., 2010; Craig et al., 2009; Fuller et al., 2006; Laffranchi et al., 2016; Reitsema et al., 2010; Toso et al., 2019). The less negative $\delta 13 \mathrm{C}$ would be the result of the consumption of millet, a $\mathrm{C}_{4}$ plant that was considered less valuable than wheat and more appropriate for feeding poultry (García Sánchez, 1996). On the other hand, studies at other sites in the area have found no such sex difference (Lubritto et al., 2017) or have attributed it to other causes (Guede et al., 2017), including the different origin of individuals. None of the females in San Baudelio reached 30 years of age as also observed in the site at Las Gobas (Guede et al., 2017). This very low life expectancy might be attributable to birth-related mortality, but mortality in females of childbearing age should not be confused with maternal mortality (Mafart, 1994), and no reliable data are available on the death of those females from their skeletons. Therefore, these lower $\delta^{15} \mathrm{~N}$ may be explained by a different origin of the females, as supported by their less negative $\delta^{13}$ Cvalues. Given the traditional family model in Castile, with 
patrilineal affiliation and patrivirilocal residence (Lisón Tolosana, 1976; Contreras, 1991), the females would likely have been borne elsewhere, so that stable isotope results at their young age would still reflect their place of origin. It should be borne in mind that isotopic values obtained from ribs reflect the food intake during the last 5 years of life (Jørkov et al., 2009) and the values observed in these very young women might reflect their diet before marrying and moving to San Baudelio. In this regard, historians (Banks et al., 1983) have affirmed that only a few families lived in San Baudelio and would need to seek ways of avoiding endogamy, especially given the prohibition of consanguineous marriage by the Catholic Church. The male SBB 16, dated to the XI century and showing a $\delta^{15} \mathrm{~N}$ value well above the mean for males, and the more negative $\delta^{13} \mathrm{C}$ value, might also have been new to the area. At any rate, oxygen isotope analyses (Lightfoot and O'Connell, 2016) are required to determine mobility and marriage patterns in these populations.

The small sample size and collective nature of the tombs make it difficult to draw conclusions about social class from the $\delta^{15} \mathrm{~N}$ results. For example, SBB-15 and SBB-16 have the highest $\delta^{15} \mathrm{~N}$ values and were buried together, but they also share the tomb with three individuals whose $\delta^{15} \mathrm{~N}$ values are around the mean for the sample, so that a social pattern cannot be clearly established. Reutilization of a tomb suggests family relationships among the individuals buried within it (Andrío and Loyola, 1992), but the chronological sequence of the burials is unknown. The male SBB- 8 and female SBB-9 share a single tomb and both show a high $\delta^{15} \mathrm{~N}$ value, which might suggest a higher social status, although other possible explanations include differences in culinary tastes or chronology. Moreover, the female skeleton has evident signs of a chronic infectious disease (currently under study) that might have increased her $\delta^{15} \mathrm{~N}$ level (D'Ortenzio et al., 2015; Reitsema, 2013).

The maxillodental disease data highlight the need to consider the age of individuals when comparing disease rates. Thus, global findings for the males might suggest that their diet was much more cariogenic in comparison to the females who would have had a diet richer in proteins of animal origin. However, this apparent sex difference can be attributed to their longer lives and consequently greater tooth wear and bacterial infection risk. In fact, the data for the young male and female adults (aged 20-40 yrs), with show no sex difference in dental disease, indicate that the diet would have been similar between the sexes. This data, together with the results of other deposits in the region (Lubritto et al., 2017) and habitat circumstances, once again support the idea that the isotopic differences between males and females do not correspond to different diets.

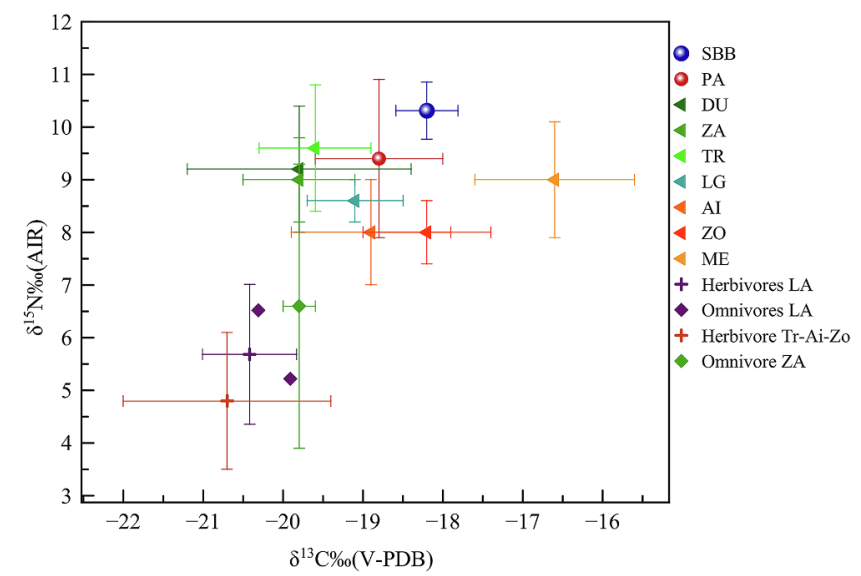

Fig 6. Scatter plot of the mean values for individuals from SBB compared with mean values reported for medieval human and faunal samples from other sites in Northern Iberia. PA: Palacios de la Sierra; DU: Dulantzi; ZA: Zaballa; TR: Treviño; LG: Las Gobas; AI: Aistra; ZO: Zornoztegi; ME: Mendraka; LA: San Martín de Lantarón.
Fig. 6 shows that higher $\delta^{15} \mathrm{~N}$ values and less negative $\delta^{13} \mathrm{C}$ values were observed in comparison to those reported for other medieval populations in Northern Iberia, such as Dulantzi, Aistra, Zaballa, Zornoztegi and Mendraka in the Basque country (Lubritto et al., 2017), Las Gobas (Guede et al., 2017), and Palacios de la Sierra (Jiménez-Brobeil et al., 2016). This graph also depicts the results obtained in animals from Northern Iberian sites in Aistra, Treviño, Zaballa, Zornoztegi (Lubritto et al., 2013, 2017; Quirós et al., 2013), and San Martín de Lantarón. Findings at these sites indicated mixed terrestrial diets with the exception of Mendraka, which is the closest to the coast and exhibited values suggesting marine diet. In San Baudelio the $\delta^{13} \mathrm{C}$ values are less negative and $\delta^{15} \mathrm{~N}$ values are higher than in these sites, which may have various explanations. On one hand, it may be attributable to geological and environmental factors, since the type of soil and climate influence the isotopic values (Goude and Fontugne, 2016; van Klinken et al., 2002). For example, water stress and soil aridity, as well as salinity, increase $\delta^{15} \mathrm{~N}$ values (Grupe et al., 2009; Szpak, 2014). All herbivores found at the aforementioned sites have similar mean $\delta^{13} \mathrm{C}$ values except for those in San Martín de Lantarón, which have less negative $\delta^{13} \mathrm{C}$ and higher $\delta^{15} \mathrm{~N}$ mean values. This may explain the mean values observed in humans from San Baudelio, although the comparison of soils between San Martín de Lantarón and San Baudelio is hampered by changes in their composition since medieval times, limiting the drawing of conclusions. On the other hand, the difference in $\delta^{15} \mathrm{~N}$ values may be explained by a larger consumption of proteins of animal origin, given that livestock farming would have been favored by the altitude of San Baudelio, and the cold winter temperatures, as at nearby sites in Upper Arlanza/Upper Douro (Padilla and Álvaro, 2008, López Pérez et al., 2016). Interestingly, shepherding was one of the activities Visigothic monks were permitted to practice, according to Sancta Communis Regula, because so many of their monasteries were in areas unsuitable for agriculture and, cereal production (Orlandis, 1973). The data of the maxillodental pathology, although scarce, are not against this explanation, since the frequencies obtained do not support a very cariogenic diet. Although no bones have been found from animals that would have grazed near San Baudelio, this first report on the province of Soria makes an important contribution to the future study of medieval populations in the North of Castile.

\section{Conclusions}

The necropolis of San Baudelio de Berlanga was used from the XI century to the middle of the XIII century, largely coinciding with the period during which the monastery of Visigothic rite was occupied. The individuals studied were peasant farmers and show fairly homogenous isotopic values. We do not have sufficient data to affirm the existence of social classes. The disparities in isotopic values between males and females are probably not related to gender dietary differences and might be explained by a patrilineal pattern of marriage and a low life expectancy of the females. In general, the diet was similar to that observed in other Northern Iberian sites of the Early Medieval period but with higher $\delta^{15} \mathrm{~N}$ values. This might be related to the more favorable conditions for stockbreeding in San Baudelio de Berlanga, with its higher altitude and colder climate, increasing their animal protein intake. We do not have the evidence required to determine the possible role of geological and other environmental factors. Analyses of strontium and oxygen isotopes are required to elucidate the dynamics of the peopling of this region.

\section{Declaration of Competing Interest}

The authors declare that they have no known competing financial interests or personal relationships that could have appeared to influence the work reported in this paper. 


\section{Acknowledgements}

This study received financial support from Research Project HAR2016-75788-P of Spanish Government. The authors are grateful to Prof. J.A. Quirós Castillo (University of Basque Country) for the animal bones from the San Martín de Lantarón site; to Richard Davies for assistance with the English version; to Profs. Rafael Martínez (University of Granada), and Marco Milella (University of Bern) for preparing Figs. 3 and 4, respectively. Many thanks also to the editor and the anonymous reviewers for their careful reading and suggestions.

\section{References}

AEMET, 2011. Atlas climático ibérico/Iberian Climatic Atlas. Agencia Estatal de Metereología, Ministerio de Medio Ambiente y Medio Rural y Marino, Madrid.

Al Oumaoui, I., 2009. Afinidades entre poblaciones antiguas de la Península Ibérica Antropología dental. $\mathrm{PhD}$ thesis. Universidad de Granada.

Al Oumaoui, I., Jiménez-Brobeil, S.A., Souich, Ph.Du., 2004. Markers of activity patterns in some populations of the Iberian Peninsula. Int. J. Osteoarchaeol. 14, 343-358.

Ambrose, S.H., 1990. Preparation and characterization of bone and tooth collagen for sotopic analysis. J. Archaeol. Sci. 17, 431-451.

Andrío, J., Loyola, E., 1992. Necrópolis medieval de San Baudelio de Berlanga. Colección de Temas Sorianos 20, 1071-1086.

Banks, Ph., Zozaya, J., Larren, H., Ceretti, Z., Bate, M., 1983. Excavaciones en San Baudelio de Casillas de Berlanga (Soria). Noticiario Arqueológico Hispánico 16, 381-440.

Bocherens, H., Biliou, D., Patou-Mathis, M., Bonjean, D., Otte, M., Mariotti, A., 1997 Paleobiological implications of the isotopic signatures (13C, 15N) of fossil mammal collagen in Scladina cave (Sclayn, Belgium). Quat. Res. 48, 370-380.

Bonsall, A.L., Pickard, C., 2015. Stable isotope and dental pathology evidence for diet in late Roman Winchester. England. J. Archaeol. Sci. Rep. 2, 128-140.

Bocherens, H., Drucker, D., 2003. Trophic level isotopic enrichment of carbon and nitrogen in bone collagen: case studies from recent and ancient terrestrial ecosystems. Int. J. Osteoarchaeol. 13, 46-53.

Bowen, W.H., Pearson, S.K., 1993. Effect of milk on cariogenesis. Caries Res. 27, 461-466.

Bownes, J., Clarke, L., Buckberry, J., 2018. The importance of animal baselines: Using isotope analyses to compare diet in a British medieval hospital and lay population. J. Archaeol. Sci. Rep. 17, 103-110.

Bronk Ramsey, C., 2017. Methods for summarizing radiocarbon datasets. Radiocarbon 59, 1809-1833.

Byers, S., 2005. Introduction to Forensic Anthropology. Allyn and Bacon, Boston.

Castillo, A. del, 1972. Excavaciones altomedievales en las provincias de Soria, Logroño y Burgos. Excavaciones arqueológicas en España, Madrid.

Castillo González, C., 2008. Evolución de los estados de salud-enfermedad de poblaciones medievales del Alto Ebro y Alto Duero. PhD thesis. Universidad de Granada.

Choy, K., Jeon, O.R., Fuller, B.T., Richards, M.P., 2010. Isotopic evidence of dietary variations and weaning practices in the Gaya cemetery at Yeanri, Gimhae, South Korea. Am. J. Phys. Anthropol. 142, 74-84.

Contreras, J., 1991. Los grupos domésticos: estrategias de producción y reproducción. In: Prat, J., Martínez, U., Contreras, J., Moreno, I. (Eds.), Antropología de los pueblos de España. Taurus, Madrid, pp. 343-380.

Coplen, T.B., 1995. New IUPAC guidelines for the reporting of stable hydrogen, carbon, and oxygen isotope-ratio data. J. Res. Natl. Inst. Stand. Technol. 100, 285.

Costa, R.L., 1980. Incidence of caries and abscesses in archeological Eskimo skeletal samples from Point Hope and Kodiak Island, Alaska. Am. J. Phys. Anthropol. 52, 501-514.

Craig, O., Biazzo, M., O’Connell, T.C., Garnsey, P., Martinez-Labarga, C., Lelli, R., Salvadei, L., Tartaglia, G., Nava, A., Reno, L., Fiammenghi, A., Rickards, O., Bondioli, L., 2009. Stable isotopic evidence for diet at the Imperial Roman coastal site of Velia (1st and 2nd Centuries AD) in Southern Italy. Am. J. Phys. Anthropol. 139, 572-583.

D'Ortenzio, L., Brickley, M., Schwarcz, H., Prowse, T., 2015. You are not what you eat during physiological stress: isotopic evaluation of human hair. Am. J. Phys. Anthropol. 57, 374-388.

DeNiro, M.J., 1985. Postmortem preservation and alteration of in vivo bone collagen isotope ratios in relation to paleodietary reconstruction. Nature 317, 806-909.

DeNiro, M.J., Epstein, S., 1978. Influence of diet on the distribution of carbon isotopes in animals. Geochim. Cosmochim. Acta 42, 495-506.

DeNiro, M.J., Epstein, S., 1981. Influence of diet on the distribution of nitrogen isotopes in animals. Geochim. Cosmochim. Acta 45, 341-351.

Díaz Martínez, P.C., 1988. Monacato y sociedad en la Hispania visigoda. Codex aquilarensis $2,47-62$.

Escolano, A., 2003. San Baudelio de Berlanga. Guía y Complementos, Necodisne, Soria Ferembach, D., Schwidetzky, I., Stloukal, M., 1979. Recommandations pour determiner l'âge et le sexe sur le squelette. Bull. Mém. Soc. Anthrop. Paris 6 (XIII), 7-45.

Fernandes, R., Nadeau, M.J., Grootes, P.M., 2012. Macronutrient-based model for dietary carbon routing in bone collagen and bioapatite. Archaeol. Anthropol. Sci. 4, 291-301.

Fuller, B.T., Molleson, T.I., Harris, D.A., Gilmour, L.T., Hedges, R.E.M., 2006. Isotopic evidence for breastfeeding and possible adult dietary differences from Late/SubRoman Britain. Am. J. Phys. Anthropol. 129, 45-54.

García-Collado, M.I., 2016. Food consumption patterns and social inequality in an early medieval rural community in the centre of the Iberian Peninsula. In: Quirós Castillo, J.A. (Ed.), Social Complexity in Early Medieval Rural Communities. The North-
Western Iberia Archaeological Record. Archaeopress Publishing, Oxford, pp. 59-78.

García de Cortázar, J.A., 1995. Las formas de organización social del espacio del Valle de Duero en la Alta Edad Media: de la espontaneidad al control feudal. In:

Despoblamiento y colonización del Valle del Duero, siglos VIII-X. Fundación Sánchez Albornoz, Ávila, pp. 11-44.

García Sánchez, E., 1996. La alimentación popular urbana en al-Andalus. Arqueología Medieval 4, 219-235.

Goude, G., Fontugne, M., 2016. Carbon and nitrogen isotopic variability in bone collagen during the Neolithic period: influence of environmental factors and diet. J. Archaeol. Sci. 70, 117-131.

Grupe, G., Heinrich, D., Peters, J., 2009. A brackish water aquatic foodweb: trophic levels and salinity gradients in the Schlei Fjord, Northern Germany, in Viking and Medieval times. J. Archaeol. Sci. 36, 2125-2144.

Guardia, M., 2011. San Baudelio de Berlanga. Una encrucijada. Memoria Artium 10, Barcelona.

Guede, I., Ortega, L.A., Zuluaga, M.C., Alonso-Olazabal, A., Murelaga, X., Solaun, J.L., Sánchez, I., Azkarate, A., 2017. Isotopic evidence for the reconstruction of diet and mobility during village formation in the Early Middle Ages: Las Gobas (Burgos, northern Spain). Archaeol. Anthropol. Sci. https://doi.org/10.1007/s12520-017 0510-9.

Guerrero, S.G., Jiménez-Brobeil, S.A., Yerro, M.V., Souich, Ph.Du., 2003. Marcadores de actividad física en San Baudelio de Berlanga (Soria). In: Aluja, P.M., Malgosa, A., Nogués, R.M. (Eds.), Antropología y biodiversidad. Bellaterra, Barcelona, pp. 246-259.

Hardy, K., Blakeney, T., Copeland, L., Kirkham, J., Wrangham, R., Collins, M., 2009. Starch granules, dental calculus and new perspectives on ancient diet. J. Archaeol. Sci. 36, 248-255.

Hedges, R., Reynard, L., 2007. Nitrogen isotopes and the trophic level of humans in archeology. J. Archaeol. Sci. 34, 1240-1251.

Hernández Barreña, D., Alonso Gavilán, G., Bécares Pérez, J., Martín Viso, I., 2013. Análisis geoarqueológico de las tumbas de El Encinar excavadas en el granito de Aldeadávila de la Ribera, Salamanca: contextualización y protocolo de trabajo. Studia Geologica Salmanticensia 49 (2), 87-134.

Herrscher, E., Fenner, J.N., Valentin, F., Clark, G., Reepmeyer, C., Bouffandeau, L., André, G., 2018. Multi-isotopic analysis of first Polynesian diet (Talasiu, Tongatapu, Kingdom of Tonga). J. Archaeol. Sci. Rep. 18, 308-317.

Hill, P.A., 1998. Bone remodelling. Br. J. Orthod. 25, 101-107.

Hillson, S., 1996. Dental Anthropology. Cambridge University Press, Cambridge.

Honch, N.V., McCullagh, J.S.O., Hedges, R.E.M., 2012. Variation of bone collagen amino acid $\delta^{13} \mathrm{C}$ values in archaeological humans and fauna with different dietary regimes developing frameworks of dietary discrimination. Am. J. Phys. Anthropol. 148, 495-511.

Jiménez-Brobeil, S.A., Laffranchi, Z., Maroto, R.M., López Sánchez, F.A., Delgado Huertas, A., 2016. How royals feasted in the court of Pedro I of Castile: A contribution of stable isotope study to medieval history. J. Archaeol. Sci. Rep. 10, 424-430.

Jørkov, M.L., Heinemeier, J., Lynnerup, M., 2009. The petrous bone: a new sampling site for indentifying early dietary patterns in stable isotopic studies. Am. J. Phys. Anthropol. 138, 199-209.

Katzenberg, M.A., 2000. Stable isotope analysis: a tool for studying past diet, demography, and life history. In: Katzenberg, M.A., Saunders, S.R. (Eds.), Biological Anthropology of the Human Skeleton. Wiley-Liss, New York, pp. 305-328.

Kjellström, A., Stora, J., Possnet, G., Linderholm, A., 2009. Dietary patterns and social structures in medieval Sigtuna, Sweden, as reflected in stable isotope values in human skeletal remains. J. Archaeol. Sci. 36, 2689-2699.

Laffranchi, Z., Delgado-Huertas, A., Jiménez-Brobeil, S.A., Granados-Torres, A., Riquelme-Cantal, J.A., 2016. Stable C \& N isotopes in 2100 Year-B.P. Human bone collagen indicate rare dietary dominance of C4 plants in NE-Italy. Sci. Rep. 6, 38817. https://doi.org/10.1038/srep38817.

Larsen, C.S., 2015. Bioarcheology. Interpreting Behaviour from the Human Skeleton. Cambridge University Press, Cambridge.

Lightfoot, E., O‘Connell, T.C., 2016. On the use of biomineral oxyten isotope data to identify human migrants in the archaeological record: intra-sample variation, statistical methods and geographical considerations. Plos One. https://doi.org/10.1371/ journal.pone.0153850.

Lisón Tolosana, C., 1976. Estructura antropológica de la familia en España. In: Rof Carballo, J. (ed.). La familia, diálogo recuperable, Karpos, Madrid, pp. 37-51.

López Pérez, M.D., Álvaro Rueda, K., Travé Allepuz, E., 2016. Rock-cut cemeteries and settlement processes at the Upper Arlanza Basin (Burgos, Spain): A Late Antique and Early Medieval landscape analysis. Zephyrus LXXVIII, 173-191.

Lubritto, C., Sirignano, C., Ricci, P., Passariello, I., Quirós Castillo, J.A., 2013. Radiocarbon chronology and paleodiet studies on the medieval rural site of Zaballa (Spain): preliminary insights into the social archaeology of the site. Radiocarbon 55 (2-3), 1222-1232.

Lubritto, C., García-Collado, M., Ricci, P., Altieri. S., Sirignano, C., Quirós Castillo, J.A. (2017) New dietary evidence on Medieval rural communities of the Basque Country (Spain) and its surroundings from carbon and nitrogen stable isotope analyses: Social insights, diachronic changes and geographic comparison. Int. J. Osteoarchaeol. DOI: 10.1002/oa.2610.

Mafart, B.Y., 1994. Approche de la mortalité maternelle au Moyen Âge en Provence. In: Buchet, L. (ed). La femme pendant le Moyen Âge et l'Époque Moderne, CNRS, Paris pp. 207-219.

Maroto, R.M., 2004. Antropología de las poblaciones femeninas medievales del Alto Ebro y Alto Duero. Universidad de Granada, Granada.

Martín Viso, I., 2007. Tumbas y sociedades locales en el centro de la península en la alta edad media: el caso de la comarca de Riba Côa (Portugal). A y TM. 14, 21-47.

Martín Viso, I., 2012. Enterramientos, memoria social y paisaje en la Alta Edad Media: 
propuestas para un análisis de las tumbas excavadas en roca en el centro-oeste de la Península Ibérica. Zephyrus LXIX 165-187.

Martín Viso, I., 2014. ¿Datar tumbas o datar procesos? A vueltas con la cronología de las tumbas excavadas en roca en la Península Ibérica. DAM 4, 29-65.

Minagawa, M., Wada, E., 1984. Stepwise enrichment of $15 \mathrm{~N}$ along food chains: further evidence and the relation between $815 \mathrm{~N}$ and animal age. Geochim. Cosmochim. Acta $48,1135-1140$

Moreno, A., Pérez, A., Frigola, J., Nieto-Moreno, V., Rodrigo-Gámiz, M., Martrat, B., González-Sampériz, P., Morellón, M., Martín-Puertas, C., Corella, J.P., Belmonte, A., Sancho, C., Cacho, I., Herrera, G., Canals, M., Grimalt, J.O., Jiménez-Espejo, M., Martínez-Ruiz, F., Vegas-Vilarrúbia, T., Valero-Garcés, B.L., 2012. The Medieval climate anomaly in the Iberian Peninsula reconstructed from marine and lake records. Quat. Sci. Rev. 43, 16-32.

Mundee, M., 2009. An isotopic approach to diet in Medieval Spain. In: Bajer, S., Allen, M., Middle, S., Poole, K. (Eds.), Food and drink in Archaeology 2. University of Nottingham, Nottingham, pp. 64-72.

Mundee, M., 2010. Exploring diet and society in Medieval Spain: new approaches using stable isotope analysis, $\mathrm{PhD}$ thesis, Durham University.

O'Connell, T.C., Kneale, C.J., Tasevska, N., Kuhnle, G.G.C., 2012. The diet-body offset in human nitrogen isotopic values: a controlled dietary study. Am. J. Phys. Anthropol. 149, 426-434.

Olsen, K.C., White, C.D., Longstaffe, F.J., Heyking, K., McGlynn, G., Grupe, G., Rühli, F.J., 2014. Intraskeletal isotopic compositions $(813 \mathrm{C}, \delta 15 \mathrm{~N})$ of bone collagen: non pathological and pathological variation. Am. J. Phys. Anthropol. 153, 598-604.

Orlandis, J., 1973. El trabajo en el monacato visigótico. Scripta theologica 5 (2), 667-684.

Ortega, L.A., Guede, I., Zuluaga, M.C., Alonso, A., Murelaga, X., Niso, J., Loza, M., Quirós, J.A., 2012. Strontium isotopes of human remains from the San Martín de Dulantzi graveyard (Alegría-Dulantzi, Álava) to infer population mobility in the Early Middle Ages. Quat. Int. 303, 54-63.

Padilla, J.L., Álvaro, K., 2008. El despoblado medieval de Cuyacabras (Burgos): Realidad, principios y argumentos. Acta historica et archaeologica mediaevalia 29, 575-604.

Padilla, J.L., Álvaro, K., 2010. Necrópolis rupestres y el poblamiento altomedieval en el Alto Arlanza (Burgos). En la España medieval 33, 259-294.

Padilla, J.L., Álvaro, K., 2013. Los asentamientos altomedievales del Alto Arlanza (Burgos). El despoblado medieval de Revenga. Pyrenae 44 (1), 11-41.

Passalacqua, N.V., Mackinnon, A.T., 2016. A historical bioarchaeology approach to health, status, and diet of Medieval Asturias, Spain. In: Quirós, J.A. (Ed.), Demografía, paleopatologías y desigualdad social en el noroeste peninsular en época medieval. UPV/EHU, Bilbao, pp. 63-82.

Powell, M.L., 1985. Analysis of dental wear and caries for dietary reconstruction. In: Gilbert, R., Mielke, J. (Eds.), The Analysis Of Prehistoric Diets. Academic Press, Orlando, pp. 307-338.

Quirós Castillo, J.A., 2011. Early medieval landscapes in north-west Spain: Local powers and communities, fifth-tenth centuries. Early Medieval Europe 19, 285-311.

Quirós Castillo, J.A., 2013. Los comportamientos alimentarios del campesinado medieval en el País Vasco y su entorno (siglos VIII-XIV). Historia Agraria 59, 13-41.

Quirós Castillo, J.A., 2014. Aristocracias, poderes y desigualdad social en la primera Edad Media en el País Vasco. In: Catalán Ramos, R., Fuentes Melgar, P., Sastre Blanco, J.C. (eds). Fortificaciones en la Tardoantigüedad: élites y articulación del territorio (siglos
V-VIII D.C.). Madrid, La Ergástula, pp. 143-158.

Quirós Castillo, J.A., Loza Uriarte, M., Niso Lorenzo, J., 2013. Identidades y ajuares en las necrópolis altomedievales. Estudios isotópicos del cementerio de San Martín de Dulantzi, Álava (siglos VI-X). Arch. Esp. Arqueol. 86, 215-223.

Reimer, P.J., Bard, E., Bayliss, A., Beck, W., Blackwell, P.G., Bronk Ramsey, C., Buck, C.E., Cheng, H., Edwards, R.L., Friedrich, M., Grootes, P.M., Guilderson, T.P., Haflidason, H., Hadjas, I., Hatté, C., Heaton, T.J., Hoffmann, D.L., Hogg, A.G., Hughen, K.A., Kaiser, F., Kromer, B., Manning, S.W., Niu, M., Reimer, R.W., Richards, D.A., Scott, E.M., Southon, J.R., Staff, R.A., Turney, C.S.M., van der Plicht, J., 2013. IntCal13 and marine13 radiocarbon age calibration curves $0-50,000$ years cal BP. Radiocarbon 55 (4), 1869-1887.

Reitsema, L.J., 2013. Beyond diet reconstruction: stable isotope applications to human physiology, health, and nutrition. Am. J. Hum. Biol. 25, 445-456.

Reitsema, L., Crews, D., Polcyn, M., 2010. Preliminary evidence for medieval Polish diet from carbon and nitrogen stable isotopes. J. Archaeol. Sci. 37, 1413-1423.

Romero, A., De Juan, J., 2007. Intra and interpopulation human buccal tooth surface microwear analysis: inferences about diet and formation processes. Anthropologie 45, 61-70.

Salazar-García, D.C., Romero, A., García-Borja, P., Subirá, M.E., Richards, M.P., 2016. A combined dietary approach using isotope and dental buccal-microwear analysis of human remains fromm the Neolithic, Roman and Medieval periods from the archaeological site of Tossal de les Bosses (Alicante, Spain). J. Archaeol. Sci. Rep. 6 , 610-619.

Schoeninger, M.J., 1985. Trophic level effects on 15N/14N and 13C/12C ratios in bone collagen and strontium levels in bone mineral. J. Hum. Evol. 14, 515-525.

Schoeninger, M.J., DeNiro, M.J., 1984. Nitrogen and carbon isotopic composition of bone collagen from marine and terrestrial animals. Geochim. Cosmochim. Acta 48, 625-639.

Schoeninger, M.J., DeNiro, M.J., Tauber, H., 1983. 15N/14N ratios of bone collagen reflect marine and terrestrial components of prehistoric human diet. Science 220, 1381-1383.

Schoeninger, M.J., Moore, K., 1992. Bone stable isotope studies in archaeology. J. World Prehist. 6, 247-296.

Szpak, P., 2014. Complexities of nitrogen isotope biogeochemistry in plant soil systems: implications for the study of ancient agricultural and animal management practices. Front. Plant Sci. 5, 1-19.

Toso, A., Gaspar, S., Banha da Silva, R., García, S.J., Alexander, M., 2019. High status diet and health in Medieval Lisbon: a combined isotopic and osteological analysis of the Islamic population from São Jorge Castle. Portugal. Archaeol. Anthropol. Sci. 11, 3699-3716.

Van Klinken, G.J., 1999. Bone collagen quality indicators for palaeodietary and radiocarbon measurements. J. Archaeol. Sci. 26, 687-695.

Van Klinken, G.J., Richards, M.P., Hedges, R., 2002. An overview of causes for stable isotopic variations in past European human populations: environmental, ecophysiological, and cultural effects. In: Ambrose, S.H., Katzenberg, M.A. (Eds.), Biogeochemical approaches to paleodietary analysis. Kluwer, New York, pp. 39-64.

Vigil Escalera, A., 2007. Granjas y aldeas altomedievales al norte de Toledo (450-800 d.C.). Arch. Esp. Arqueol. 80, 239-284. 